\title{
MICROALLOYED STEELS FOR THE AUTOMOTIVE INDUSTRY
}

Debanshu Bhattacharya'

\begin{abstract}
Two major drivers for the use of newer steels in the automotive industry are fuel efficiency and increased safety performance. Fuel efficiency is mainly a function of weight of steel parts, which in turn, is controlled by gauge and design. Safety is determined by the energy absorbing capacity of the steel used to make the part. All of these factors are incentives for the U.S. automakers to use both Highly Formable and Advanced High Strength Steels (AHSS) to replace the conventional steels used to manufacture automotive parts in the past. AHSS is a general term used to describe various families of steels. The most common AHSS is the dual-phase steel that consists of a ferrite-martensite microstructure. These steels are characterized by high strength, good ductility, low tensile to yield strength ratio and high bake hardenability. Another class of AHSS is the complex-phase or multi-phase steel which has a complex microstructure consisting of various phase constituents and a high yield to tensile strength ratio. Transformation Induced Plasticity (TRIP) steels is another class of AHSS steels finding interest among the U.S. automakers. These steels consist of a ferrite-bainite microstructure with significant amount of retained austenite phase and show the highest combination of strength and elongation, so far, among the AHSS in use. High level of energy absorbing capacity combined with a sustained level of high $n$ value up to the limit of uniform elongation as well as high bake hardenability make these steels particularly attractive for safety critical parts and parts needing complex forming. A relatively new class of AHSS is the Quenching and Partitioning (Q\&P) steels. These steels seem to offer higher ductility than the dual-phase steels of similar strengths or similar ductility as the TRIP steels at higher strengths. Finally, martensitic steels with very high strengths are also in use for certain parts. The most recent initiative in the area of AHSS is the so-called "3rd Generation" AHSS. These steels are designed to fill the region between the dual-phase/TRIP and the Twin Induced Plasticity (TWIP) steels with very high ductility at strength levels comparable to the conventional AHSS. Enhanced Q\&P steels may be one method to achieve this target. Other ideas include TRIP assisted dual phase steels, high manganese steels and carbide-free bainitic (CFB) steels. Finally the post hardened steels (PHS) are an important component of the strategy of future vehicles. In this paper, some of the above families of advanced formable and high strength steels with micro-alloying additions, utilized in the automotive industry will be discussed.
\end{abstract}

Keywords: AHSS; Automotive; Microalloyed.

\section{INTRODUCTION}

Initially microalloyed steels essentially referred to what is now called HSLA steels. These were plain C-Mn steels with additions of microalloying elements such as $\mathrm{Ti}$, $\mathrm{Nb}$ and $\mathrm{V}$. However, in the quest for fuel economy, automobile manufacturers needed to reduce weight and this translated to reduced thickness of steel sheets. This led to the explosive growth in the use of higher and higher strength steels for the manufacture of automobiles.

Their applications can be broadly classified into: outer body panels and body-in-white parts. In the case of outer body panels, the major driver is weight reduction. This translates to more formable steels for manufacture of complex- design parts as well as part consolidation. In addition, reduction of gauge for weight savings has led to the use of high strength IF and IF-bake hardenable steels.

For the body-in-white parts, major drivers have been reductions of weight as well as increased emphasis on safety performance. In these applications, the focus, therefore, has been on first, development of higher and higher strength steels with good formability for gauge reduction, and second, in steels with higher energy absorption capacity for safety enhancement parts. Steels for the first type of application include multi-phase (complex phase) steels and dual phase (DP) steels. The second type of applications include dual phase but particularly the Transformation Induced Plasticity (TRIP) steels. Finally, fully martenisiitic steels are used for many safety critical parts requiring very high strength. These were termed the "First Generation" Advanced High Strength Steels ( ${ }^{\text {st }}$ Gen AHSS).

The next advancement in this quest for weight reduction was to increase the complexity of parts so as to reduce the number of welds. This needed AHSS with very high ductility and this led to the development of Twin Induced Plasticity (TWIP), Light Induced Plasticity (LIP) and austenitic stainless steels. These were termed the Second Generation of AHSS ( $2^{\text {nd }}$ Gen AHSS).

These steels proved to be difficult to manufacture and expensive. Therefore, the so-called "Third Gene-

'Materials Sciences, Ph.D., Director, Product Research, ArcelorMittal Global R \& D, East Chicago, Indiana, USA. E-mail: debanshu.bhattacharya@ arcelormittal.com 
ration" AHSS ( $3^{\text {rd }}$ Gen AHSS) were developed and are designed to fill the region between the DP/TRIP (I ${ }^{\text {st }} \mathrm{Gen}$ ) and the TWIP (2 ${ }^{\text {nd }}$ Gen) AHSS. These are schematically shown in Figure $\mathrm{I}$.

Many new ideas are being explored to achieve the targets of the $3 \mathrm{G}$ AHSS. A relatively new class is the Quenching and Partitioning (Q\&P) steels. These seem to offer higher ductility than DP steels of similar strengths or similar ductility as the TRIP steels at higher strengths. The most recent initiative in the area of AHSS is with very high ductility at strength levels comparable to conventional AHSS. Here, enhanced Q\&P steels may be a candidate. Other ideas include Ferro-Austenitic steels, TRIP assisted DP steels, high Mn steels and higher carbon TRIP type steels.

Almost all of these steels use some microalloying element to one extent or another. In addition to the traditional microalloying additions of $\mathrm{Ti}, \mathrm{Nb}$ and $\mathrm{V}$, these steels also contain significant amounts of one or more of the following; Mo, $\mathrm{Cr}, \mathrm{Mn}, \mathrm{Si}, \mathrm{Al}$ and $\mathrm{B}$.
In this paper, the HSLA, the highly formable steels such as the IF steels and the $2^{\text {nd }}$ Gen AHSS such as TWIP will not be discussed but rather the paper will focus on the I ${ }^{\text {st }}$ Gen AHSS and the $3^{\text {rd }}$ Gen AHSS.

\section{2 | $^{\text {st }}$ GENERATION AHSS}

\section{I Dual Phase Steels}

Among AHSS, dual phase steels have the widest usage among automakers. This is because they provide an excellent combination of strength and ductility while at the same time are widely available due to the relative ease of manufacture. As a result, a large number of dual phase products have been developed and used.

Table $\mathrm{I}$ is a summary of the dual phase product property requirements. Requirements for the same product sometimes vary widely; hence only representative property

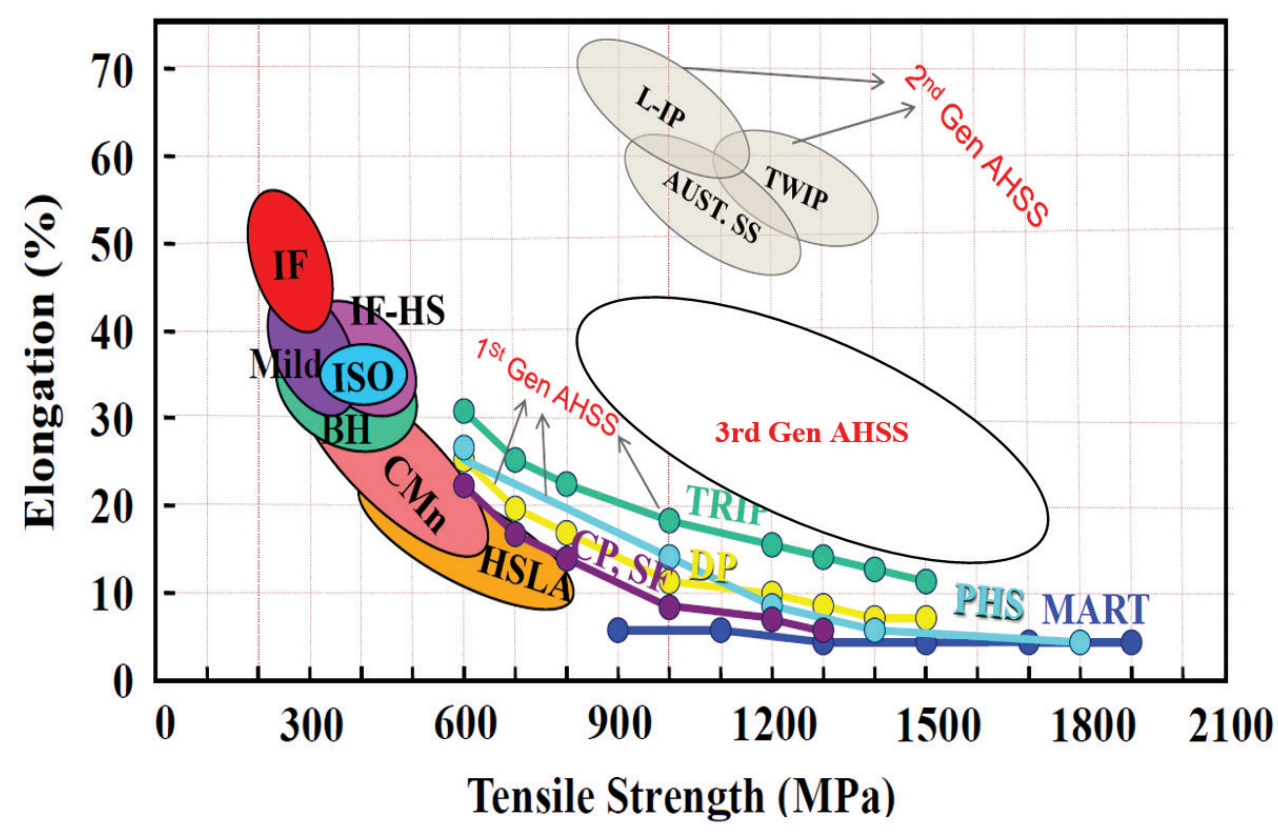

Figure I. Ductility - Strength relationship of steels including ${ }^{\text {st }}$ Gen, $2^{\text {nd }}$ Gen and $3^{\text {rd }}$ Gen AHSS.

Table I. Dual Phase steels and their mechanical property requirements

\begin{tabular}{lccc}
\multicolumn{1}{c}{ Product } & TS (MPa) $\mathbf{m i n}$. & YS (MPa) & TE (\%) min. \\
\hline Cold Rolled 590 MPa Dual Phase (CR 590 DP) & 590 & $305-450$ & 24 \\
Cold Rolled 780 MPa Dual Phase (CR 780 DP) & 780 & $420-550$ & 14 \\
Cold Rolled 980 MPa Dual Phase (CR 980 DP) & 980 & $600-720$ & 10 \\
Galvanized 600 MPa Dual Phase (GI 590/600 DP) & 600 & $340-410$ & 23 \\
Galvanized 780 MPa Dual Phase (GI 780 DP) & 780 & $420-550$ & 14 \\
Galvannealed 590 MPa Dual Phase (GA 590 DP) & 590 & $300-410$ & 23 \\
Galvannealed 780 MPa Dual Phase (GA 780 DP) & 780 & $440-560$ & 12 \\
Galvannealed 980 MPa Dual Phase (GA 980 DP) & 980 & $600-720$ & 10 \\
Cold Rolled I I80 MPa Dual Phase (CR II80 DP) & 1180 & $850-1020$ & 8 \\
Galvannealed I I80 MPa Dual Phase (GA II80 DP) & 1180 & $800-970$ & 8 \\
\hline
\end{tabular}


targets are listed. Also, requirements of total elongation depend on steel gauge; values shown here are for 1.6-2.0 $\mathrm{mm}$ range. Finally, the test results are for JIS-T samples except for GI 600 DP where it is ASTM-L.

All the steels developed are based on annealing in the two-phase (inter-critical) temperature region and the consequent increase in carbon content in austenite in comparison with the average carbon content in the steel. Higher carbon content in austenite after inter-critical annealing results in a significant shift of pearlite transformation towards lower temperature and slower cooling rates. It is clear that the relative fraction of the formed ferrite always increases, and significantly at certain cooling rates.

The effect of inter-critical annealing is not confined only to higher $C$ in comparison with the fully austenitized condition. The acceleration of "new ferrite" formation due to the presence of pre-existing phase boundaries and corresponding repartitioning of carbon has very important consequences for production of dual-phase and TRIP steels. In particular, the resulting enrichment of remaining austenite by carbon completely suppresses bainite reaction and evidently decreases $M_{s}$ temperature at lower cooling rates. In other steels, as shown by the author, it shifts the bainite transformation toward lower cooling rates.

Microalloying additions to AHSS steels for the automotive industry are mainly $\mathrm{Ti}$ and $\mathrm{Nb}$ ( $\mathrm{V}$ is used mostly for non automotive applications). Let us discuss their effects singly and in combination.

$\mathrm{Nb}$ plays several important roles in dual phase steels. The first major role played by $\mathrm{Nb}$ is the generation of a finer hot rolled grain size and consequently a final microstructure. The effect of $\mathrm{Nb}$ on microstructures is shown in Figure 2 [ I] and will be discussed later.

This, in turn, leads to two benefits. First, it is believed that a finer microstructure results in lower variability of properties. This is important as property variability is an ongoing concern in dual phase steels. Second, a finer grain size reduces banding resulting from the invariable high $\mathrm{Mn}$ content in these steels. Reduced banding contributes to improved bendability, which is important for the manufacture of certain parts $[2,3]$.

$\mathrm{Nb}$ has a major role in transformation kinetics. This starts with its effect on austenization. (Figure 3 ) displaying the measured amount of austenite as a function of heating temperature, demonstrate that at the same intercritical temperature, the steel with $0.03 \% \mathrm{Nb}$ displays a larger volume of austenite than a "no-Nb" steel [4].

This means that additions of $\mathrm{Nb}$ accelerate the austenitization process. Evidently, the refinement of the initial hot rolled structure creates more defects, such as interface boundaries, for example, which could serve as nuclei for austenite formation.

Microstructures shown in Figure 2 show interesting features. Figures 2a-d show the SEM images of hot rolled steels which were coiled at $620^{\circ} \mathrm{C}$. Figures 2e-h display the SEM/EBSD results of cold rolled steels with various
$\mathrm{Nb}$ contents $(0 \%, 0.02 \%, 0.04 \%$ and $0.06 \%$ wt. $\mathrm{Nb}$ ) after annealing. Figures $2 \mathrm{i}-\mathrm{I}$ represent grain boundary misorientation maps. The red lines indicate the grain boundaries with misorientation between 2 to 5 degrees, the green lines represent the grain boundaries with misorientation between 5 to 15 degrees, and the blue lines show the grain boundaries with misorientation between 15 to 65 degrees, i.e., high-angle grain boundaries (HAGB). As shown in Figure 2 , the addition of $0.02 \% \mathrm{Nb}$ results in a decrease in high-angle grain boundaries of ferrite, grain size of ferrite, and volume fraction of recrystallized ferrite- $F$ (Volume of ReX F divided by Volume of F). This can be attributed to the pinning effect of soluble $\mathrm{Nb}$ and $\mathrm{Nb}$ precipitates which retard ferrite recrystallization and slow down ferrite grain growth.

Figures $2 m-p$ show the kernel average misorientation map. The black area represents martensite and the color key displays kernel average misorientation. The color variation from blue to red represents the increase in misorientation inside a grain. The inverse pole figures in Figures 2q-t highlight recrystallized ferrite, which contains very low dislocation density and high-angle grain boundaries. Each single color in Figures $2 q-t$ corresponds to one unique orientation as shown in the color coded triangle map in Figure 2t. Every recrystallized ferrite grain is presented by a homogeneous color and orientation. The different colors in recrystallized ferrite grains imply that there is no orientation preference for ferrite recrystallization in the dual-phase steels investigated.

The effect of $\mathrm{Nb}$ on the mechanical properties of a dual phase steel is shown in Figure 4. As can be seen additions of $\mathrm{Nb}$ increase both the tensile and yield strengths. In the steel without $\mathrm{Nb}$, the maximum TS is around $970 \mathrm{MPa}$; an increase in $\mathrm{Nb}$ content to $0.040 \%$ raises the TS up to $\sim 1200 \mathrm{MPa}$. Further increase in $\mathrm{Nb}$ content up to $0.06 \%$ does not increase the TS level further [I]. As shown in Figure 2 , the addition of a small amount of $\mathrm{Ti}(0.02 \%)$ does not influence the strength in the steels coiled at $500^{\circ} \mathrm{C}$ (Figure $5 \mathrm{~b}$ ), but decreases the strength in the $\mathrm{Nb}$ added steels in the case of $620^{\circ} \mathrm{C}$ coiling temperature (Figure 5a). This is in agreement with the influence of $\mathrm{Ti}$ on $\mathrm{Nb}$ precipitation.

Such a strong increase in TS with increasing content of $\mathrm{Nb}$ cannot be explained only by the traditional strengthening mechanisms of grain refinement and precipitation hardening, but only by a change in the carbon containing phase such as martensite and/or bainite. Figure 5 shows the variation of the measured volume of martensite with increasing $\mathrm{Nb}$ content at two coiling temperatures and with or without Ti. Martensite volume fraction follows the same trend as the tensile strength curves shown above.

Assuming that every percent of martensite adds $\sim 9 \mathrm{MPa}$ strength $[5,6]$, the additional $17 \%$ of martensite (66\% minus $49 \%$ ) contributes an extra I53 MPa strength in the $2 \mathrm{Nb}$ steel in comparison with the $\mathrm{Nb}$ free steel. Thus, it can be concluded that an increase in martensite fraction 


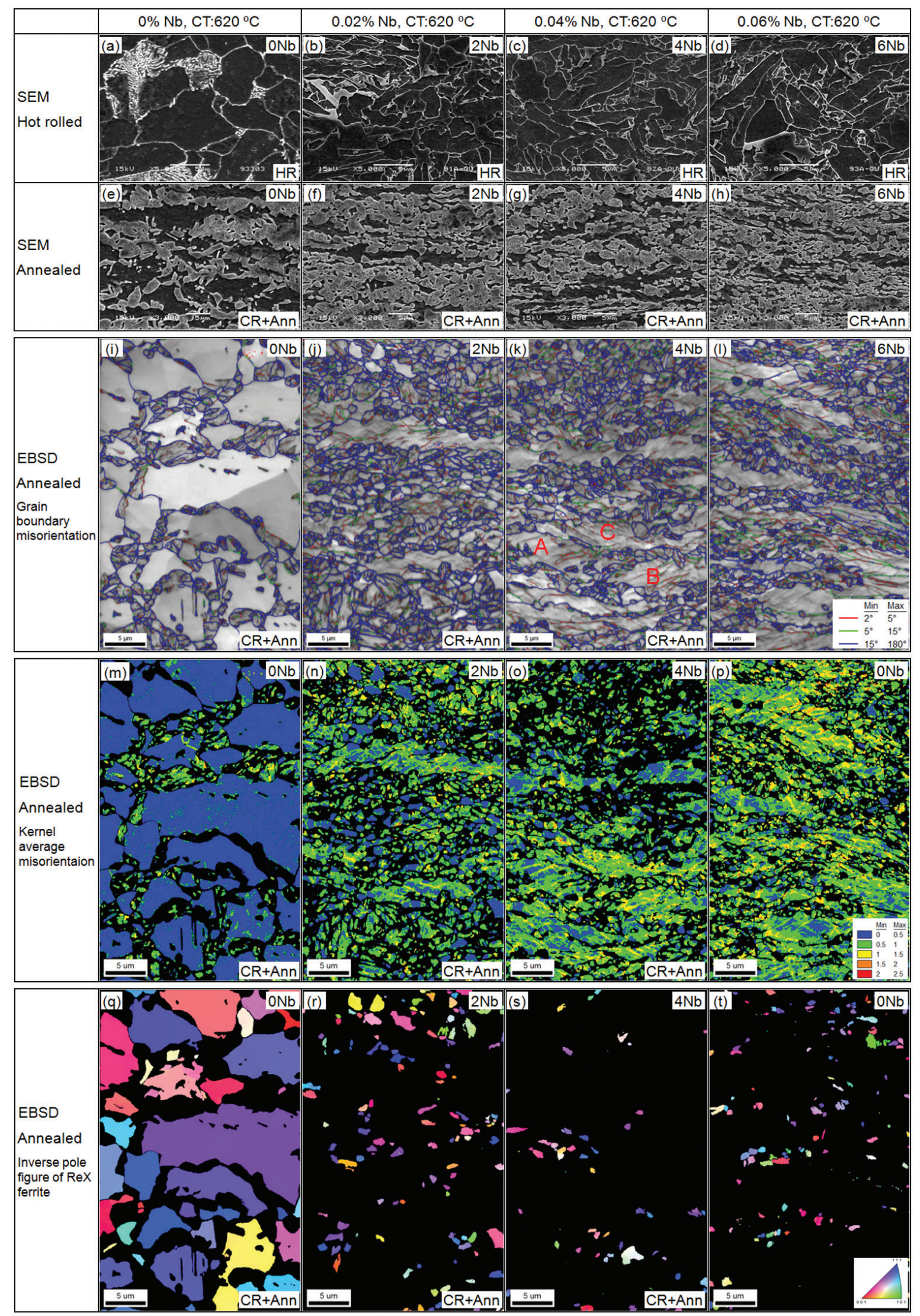

Figure 2. Effect of $\mathrm{Nb}$ content on microstructure of the Ti free cold rolled and annealed steels (e-t) (CT: $\left.620^{\circ} \mathrm{C}\right)$. (a-d) SEM of hot bands; (e-h) SEM of annealed steels; ( $\mathrm{i}-\mathrm{I})$ grain boundary misorientation maps; $(\mathrm{m}-\mathrm{p})$ kernel average misorientation maps; and (q-t) Inverse pole figures of Recrystallized ferrite [I]. 


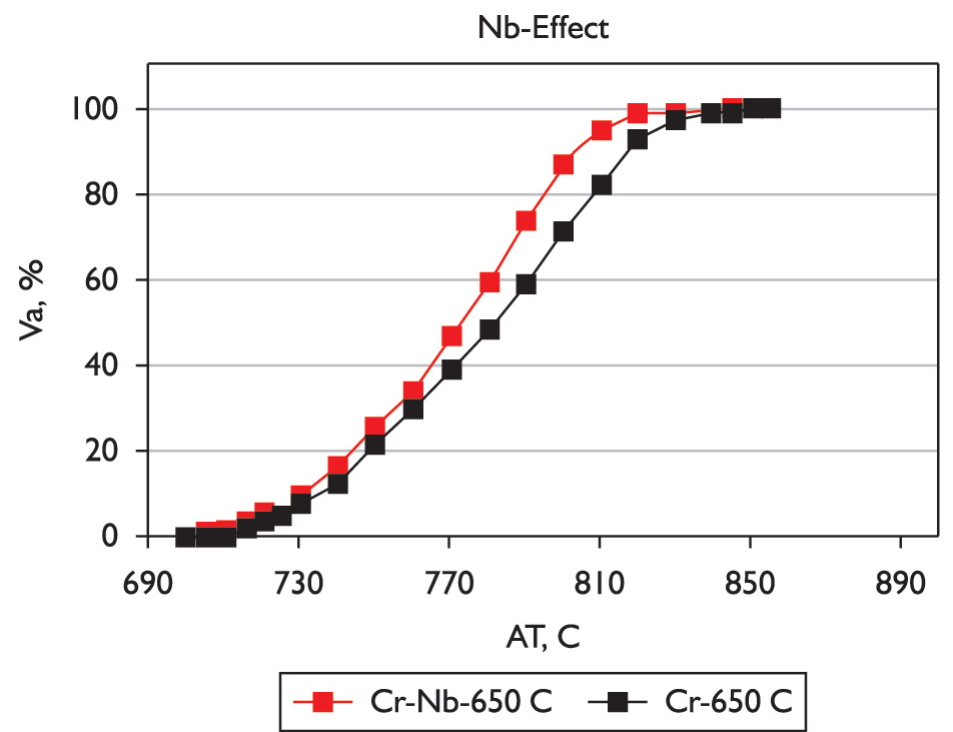

Figure 3. Effect of $\mathrm{Nb}$ on austenitization as a function of annealing temperature [4].
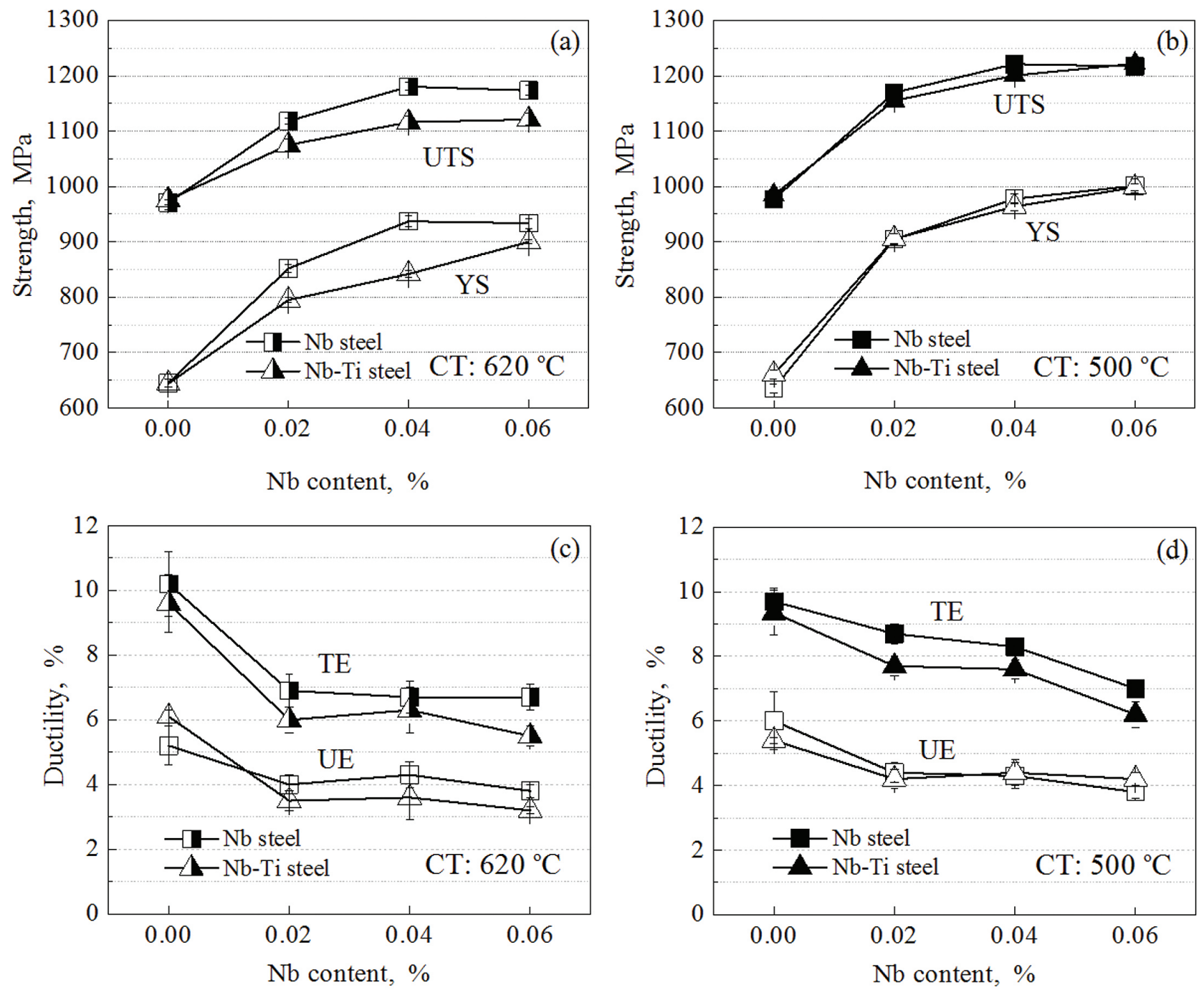

Figure 4. Effect of $\mathrm{Nb} / \mathrm{Ti}$ additions on the tensile strength (a-b) and ductility (c-d) of annealed steels; $(\mathrm{a}, \mathrm{c})$ coiling temperature of $620^{\circ} \mathrm{C},(\mathrm{b}, \mathrm{d})$ coiling temperature of $500^{\circ} \mathrm{C}[\mathrm{I}]$. 
provides a substantial contribution to the increase in TS of the investigated steels at the same annealing temperature.

The nature of strengthening by martensite in DP steel is illustrated in Figure 6a, which shows a large amount of dislocation structures within martensite and at ferrite-martensite (F-M) interfaces. The kernel average misorientation map in Figure $6 \mathrm{~b}$ reveals considerable misorientation gradients spreading from the ferrite-martensite phase boundaries into the ferrite grain interior. In the case of a high number of martensite neighbors, some ferrite grains, e.g., "grain I" in Figure 6b, is significantly work-hardened by the volume accommodation during austenite to martensite transformation.

A very small amount or even nearly no $\mathrm{Nb}$ precipitation was found in the hot rolled steels after coiling at $500^{\circ} \mathrm{C}$, while for the steels coiled at $620^{\circ} \mathrm{C}$, about $50-65 \%$ of $\mathrm{Nb}$ is present as precipitates. Among these precipitates, the small and round shaped $\mathrm{NbC}$ precipitates in the Ti added steel (Figure 6a) coexist with large cubic/rectangular shaped

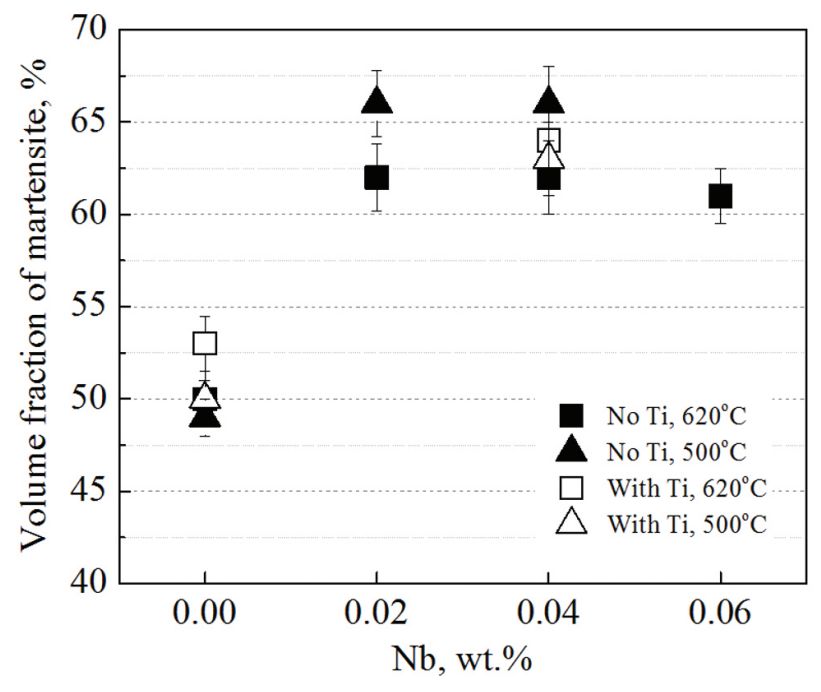

Figure 5. Volume fraction of martensite as a function of $\mathrm{Nb}$ content in the steel with or wihout $\mathrm{Ti}$ [I].
Ti precipitates as $(\mathrm{Ti}, \mathrm{Nb})(\mathrm{C}, \mathrm{N})$ (Figures $7 \mathrm{~b}-\mathrm{c})$. The large size of $\mathrm{Ti}-\mathrm{Nb}$ precipitates is less efficient in microstructure refinement during hot rolling and subsequent annealing. Precipitation hardening is also weakened with the increase in particles size. As a result, coarse microstructure and lower strength (Figure 2) are obtained in the $\mathrm{Nb}-\mathrm{Ti}$ steels coiled at $620^{\circ} \mathrm{C}$.

\subsection{Complex Phase Steels}

Complex-phase steels, also sometimes referred to as Multi-phase steels, are high strength steels characterized by high tensile and yield strength combined with moderate elongation. Such steels are gaining popularity in the U.S. in recent times.

Sometimes an added feature of these steels is high stretch flangeability generally measured by hole expansion tests. The microstructures of these steels generally constitute several phases such as ferrite, pearlite, bainite and (tempered) martensite. To obtain the high YS/TS ratio, different metallurgical principles need to be used for cold rolled and for galvannealed products. For cold rolled steels, achievement of higher YS/TS ratio of $>0.7$ is possible with a higher overage temperature on an appropriate dual phase structure. For galvannealed steels, however, higher YS cannot be obtained from an initial dual phase structure since in the galvannealing process, martensite is formed only in the final step of air-cooling and no further overaging is possible. The only way to gain yield strength in galvannealed multiphase structure is to obtain appropriate mixture of pearlite and bainite.

The temperature of bainite appearance as a structure constituent in the martensite/bainite mixture can be used as an indirect indicator of austenite stability. The effect of $\mathrm{Nb}$ content on this temperature is presented in Figure 8. As shown, an increase in $\mathrm{Nb}$ additions increases the annealing temperature when bainite was detected in the structure. Thus addition of $\mathrm{Nb}$ enhances the formation of bainite, necessary to produce multi-phase products.
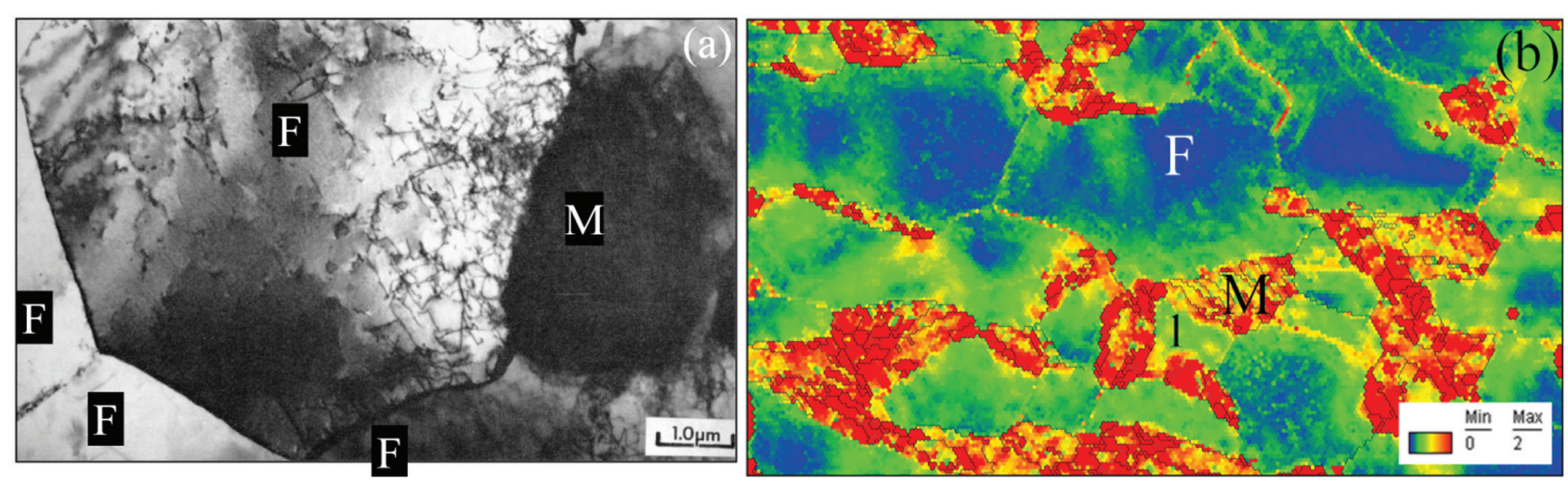

Figure 6. TEM (a) and EBSD kernel average misorientation map (b) of DP steel, which shows a large amount of dislocation structures within Martensite and at Ferrite-Martensite interfaces [I]. 

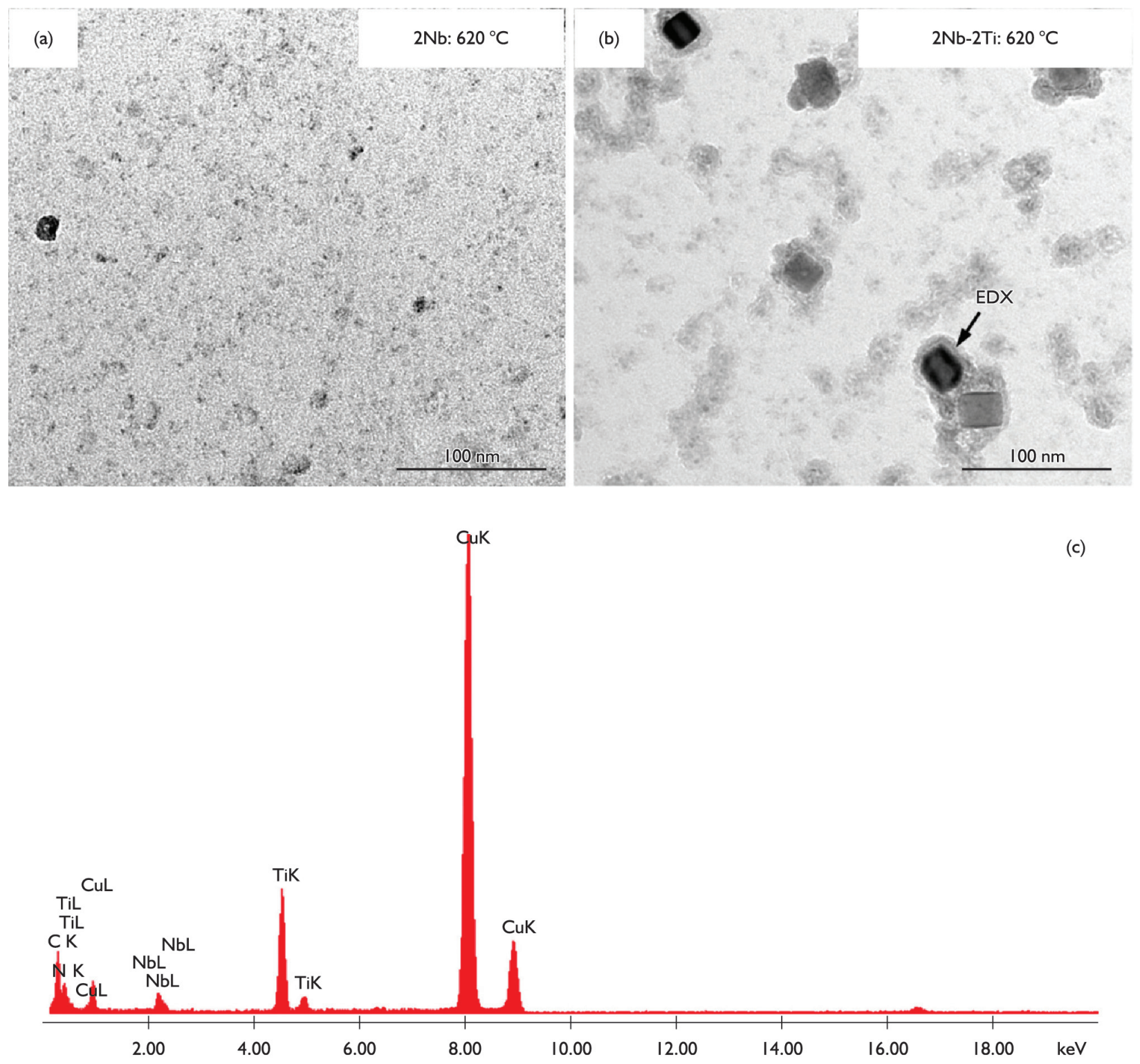

Figure 7. TEM images of precipitates using extraction carbon replicas in the $2 \mathrm{Nb}$ (a) and $2 \mathrm{Nb}-2 \mathrm{Ti}$ steels (b), for coiling temperature of $620^{\circ} \mathrm{C}$. (c) EDX spectrum identifies the square/rectangular shaped precipitate in (b) as $(\mathrm{Ti}, \mathrm{Nb})(\mathrm{C}, \mathrm{N})[\mathrm{I}]$.

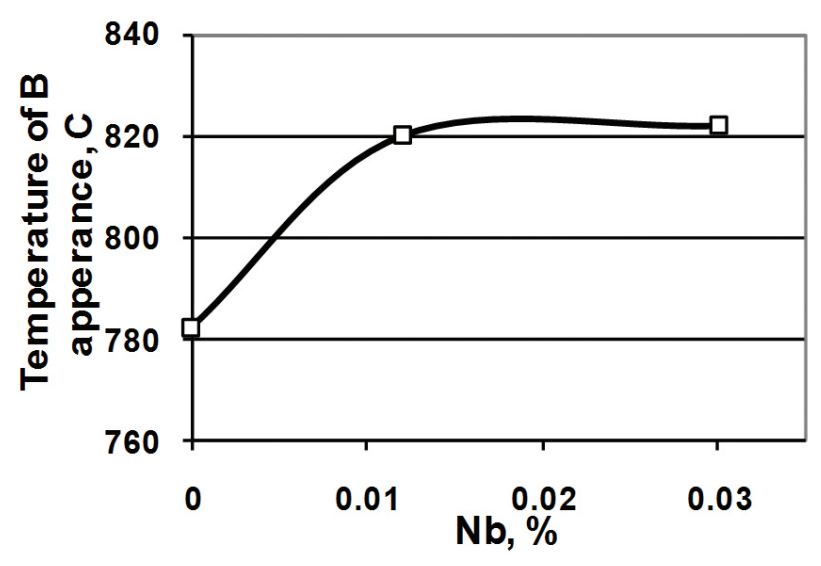

Figure 8. Effect of $\mathrm{Nb}$ on the annealing temperature for first appearance of bainite [7].
$\mathrm{Nb}$ is also added to achieve strengthening by precipitation hardening as well as by refined grain size through solute drag effects.

Typical microstructure for a complex-phase steel is shown in Figure 9.

Based on these principles, complex-phase steels are produced in hot-rolled, cold-rolled and galvanized/galvannealed conditions, ranging in strength from 590 to $980 \mathrm{MPa}$. For more information, please see references [8], [9] and [10].

\subsection{TRIP Steels}

Transformation Induced Plasticity (TRIP) steels, as is well known, are steels with a ferrite, bainite and retained austenite microstructure. As a result, these steels offer a combination of high strength with excellent formability in 
terms of both elongation and $\mathrm{n}$ (strain hardening exponent) value. This high level of energy absorbing capacity is ideal for certain crash resistant parts. At the same time, the high formability allows for manufacture of complex parts.

The major positive effects of $\mathrm{Nb}$ addition in TRIP steels are:

- $\mathrm{Nb}$ in solid solution increases the stability of austenite; this contributes to the presence of retained austenite in the final microstructure.

- Nb refines the hot rolled grain structure and thus the final microstructure. This improves the strength as well as other aspects of performance.

- Nb provides some precipitation hardening contributing to strengthening of the product.
- Nb facilitates the bainite reaction, particularly at temperatures of galvannealing. This is clearly shown in Figure 10 [I I] from work at ArcelorMittal (G2, G3, G4 being 0.02, 0.03 and $0.04 \%$ $\mathrm{Nb})$. Because of increased bainite formation at a faster rate, it is possible to enrich the remaining austenite with carbon and stabilize it. As a result, it is retained as austenite in the final structure, even at the relatively low times of holding during galvannealing in a continuous line.

- Nb increases bake hardenability.

- Nb has no deleterious effects on the galvannealing reaction in these steels.
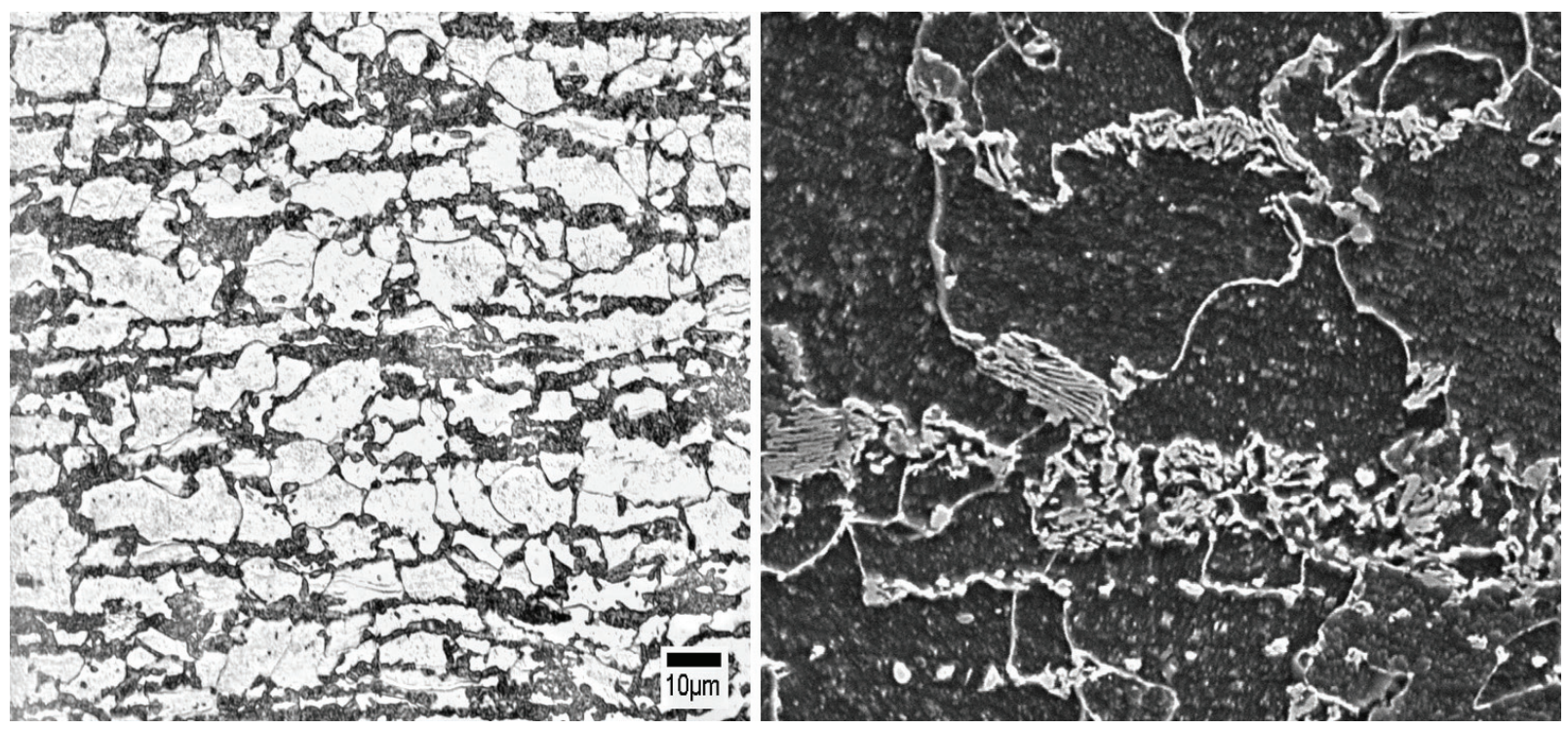

Figure 9. Typical microstructure of a complex-phase steel.
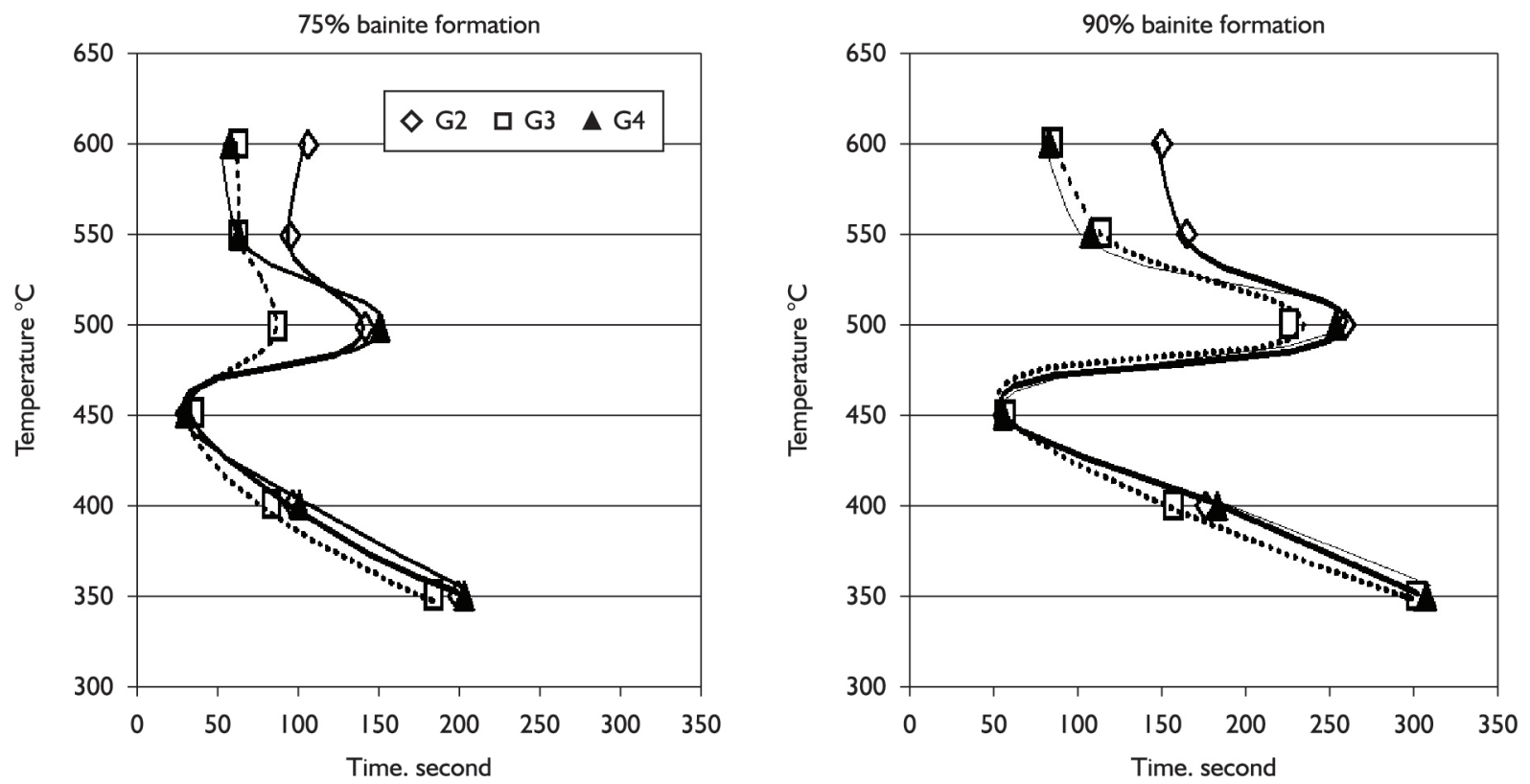

Figure 10. Effect of Nb on Bainite Transformation in a TRIP Steel [I I]. 

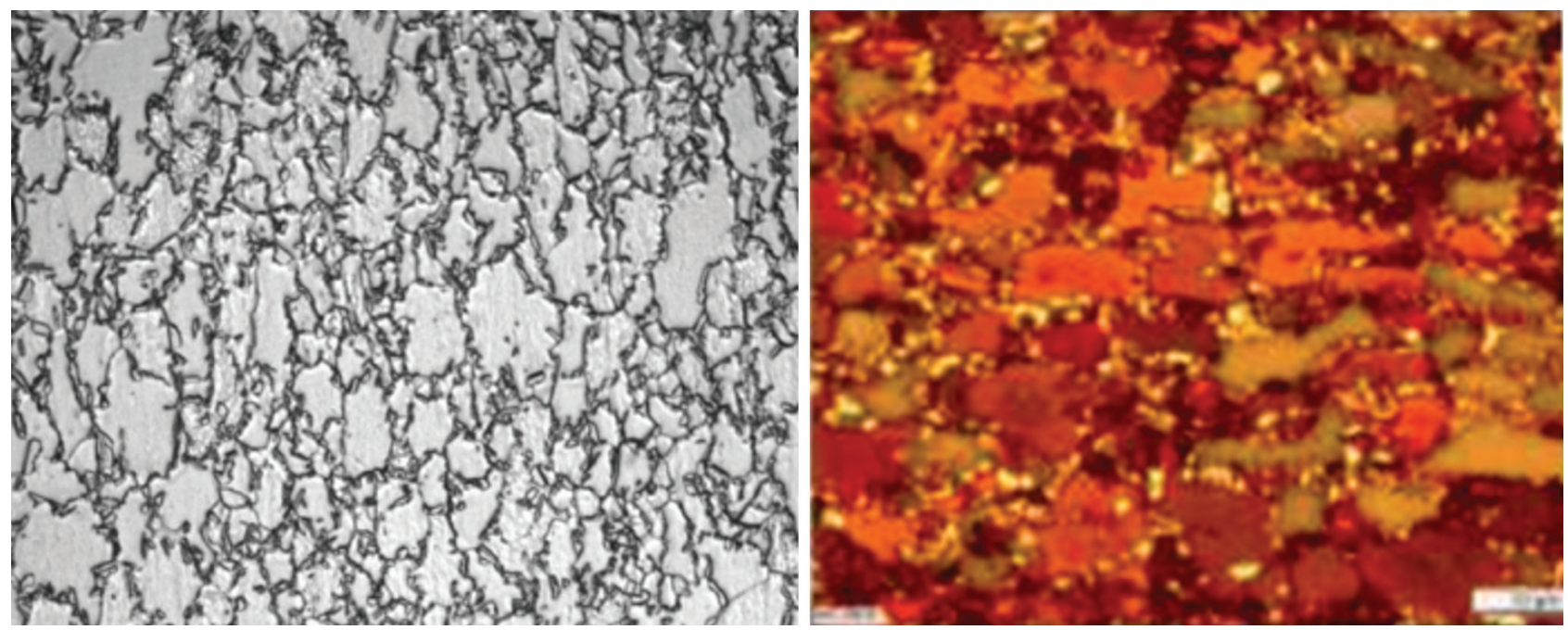

Figure I I. Typical microstructure of a TRIP steel.

Typical microstructure of a TRIP steel is shown in Figure II.

\subsection{Martensitic Steels}

Using water quenching in a continuous annealing line, steels with $100 \%$ martensite are produced. These steels offer very high strength although ductility is lower than other advanced high strength steels. The strength of the steel is controlled by the carbon content and a complete austenitizing temperature is used to obtain a fully martensitic structure. Using this method, martenisitic steels from 900 to $1500 \mathrm{MPa}$ are produced commercially.

Typical microstructure of a martensitic steel is shown in Figure 12.

$\mathrm{Nb}$ in amounts of about $0.015 \%$ is added to these steels mainly to obtain a more refined structure. This leads to more uniformity in mechanical properties.

\section{$33^{\text {rd }}$ GENERATION AHSS}

As stated previously, the $3^{\text {rd }}$ Gen AHSS are meant to fill the region between the $I^{\text {st }} \mathrm{Gen}$ and the $2^{\text {nd }} \mathrm{Gen}$ AHSS. There are many different steels being developed to fill this gap, but they can be broadly divided into two classes. The first, often called AHSS-HF are steels with current tensile strength $(980$, I I $80 \mathrm{MPa}$ etc.) but with higher yield strength, elongation and HER. The second type called, AHSS-HSHF, are steels with even higher requirements of strength and formability. Some typical examples of such steels are given in Table 2.

\section{I TRIP Assisted Dual-Phase (High Si) Steels}

As is evident, the $3^{\text {rd }}$ generation HF products need higher elongation and HER (Hole Expanding Ratio) than the $I^{\text {st }}$ Gen steels of the same type. One way, perhaps the only,to achieve this combination is the addition of $\mathrm{Si}$. The

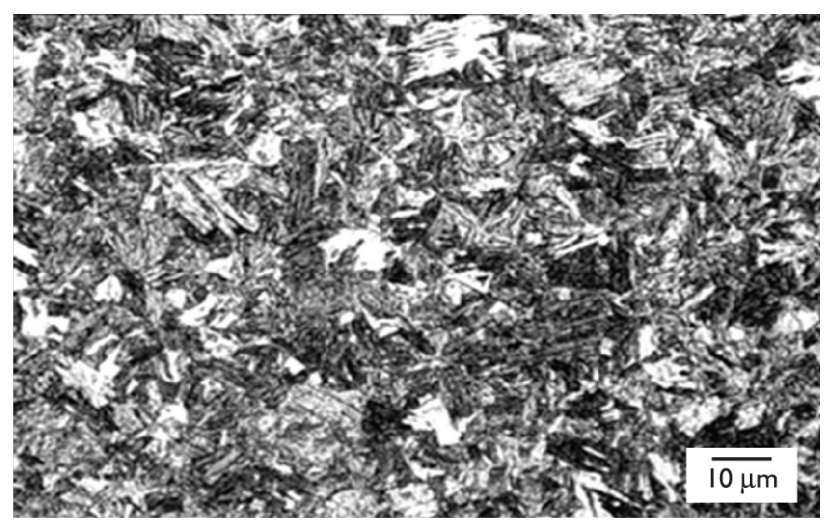

Figure 12. Typical microstructure of a martensitic steel.

effect of Si on strength and elongation is shown in Figure 13 [12].

This can be explained by the fact that that strengthening by $\mathrm{Si}$ increases the strength of ferrite (approximately by 90-I20 MPa/\% [13]. This allows reaching the same strength of DP steel at a lower amount of martensite which then leads to higher elongation.

Generally there is an inverse relationship between elongation and HER so that as elongation is increased, it becomes more difficult to improve HER. Again one element that improves both is $\mathrm{Si}$. The effect of $\mathrm{Si}$ on these properties is shown in Figure 14 [14].

The beneficial effect of addition of $\mathrm{Nb}$ for both strength and ductility is well known and can be best depicted in the Figure 15.

\subsection{Austenite Martensite (Medium Mn) Steels}

One other alloy design which has received a lot attention has been steels containing 4-8\% Mn. As early as 1972, Miller [15] investigated a $0.11 \% \mathrm{C}, 6 \% \mathrm{Mn}$ steel which contain $60-70 \%$ polygonal ferrite and $30-40 \%$ 
Table 2. Mechanical Property Targets for initial $3^{\text {rd }}$ Generation AHSS

\begin{tabular}{lcccc}
\hline \multicolumn{1}{c}{ Product } & TS (MPa) min. & YS (MPa) min & TE (\%) min. & HER (\%) min \\
\hline Cold Rolled/Galvanized/Galvannealed $980 \mathrm{MPa} \mathrm{HF}$ & 980 & 600 & 21 & 20 \\
Cold Rolled/Galvanized/Galvannealed I I80 MPa HF & 1180 & 850 & 14 & 30 \\
\hline
\end{tabular}
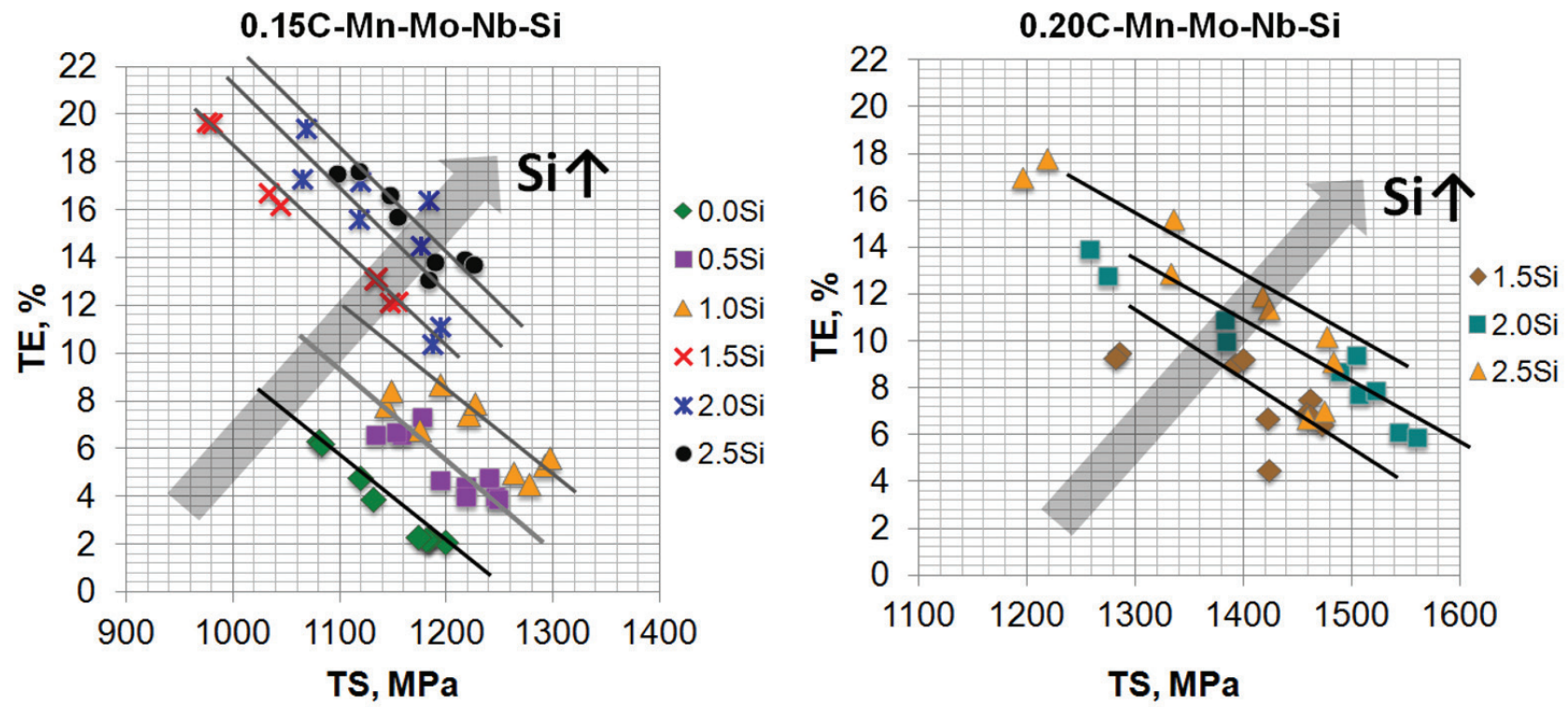

Figure 13. Effect of Si on TS-TE balance of Mn-Mo-Nb (wt.\%) steels with 0.15 and $0.20 \% \mathrm{C}$.

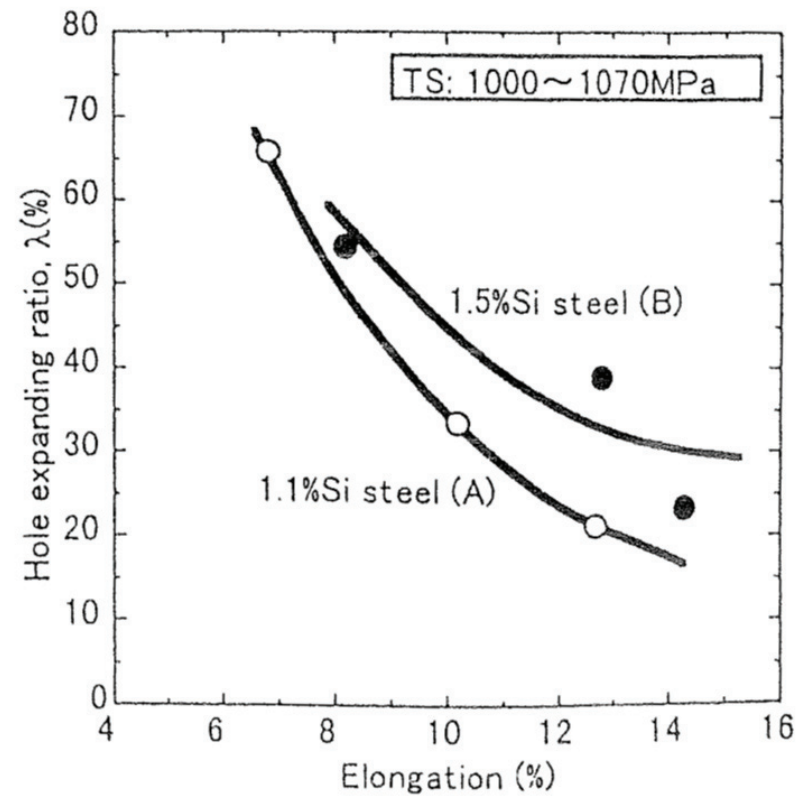

Figure 14. Relationship between elongation and HER as a function of $\mathrm{Si}$ in a dual- phase steel [14].

retained austenite to achieve high strength and ductility. The stress -starin curve and a typical microstructure of this steel is shown in Figure 16.

This concept has been advanced by Matlock et al. [16] to suggest that high austenite stability can be used to

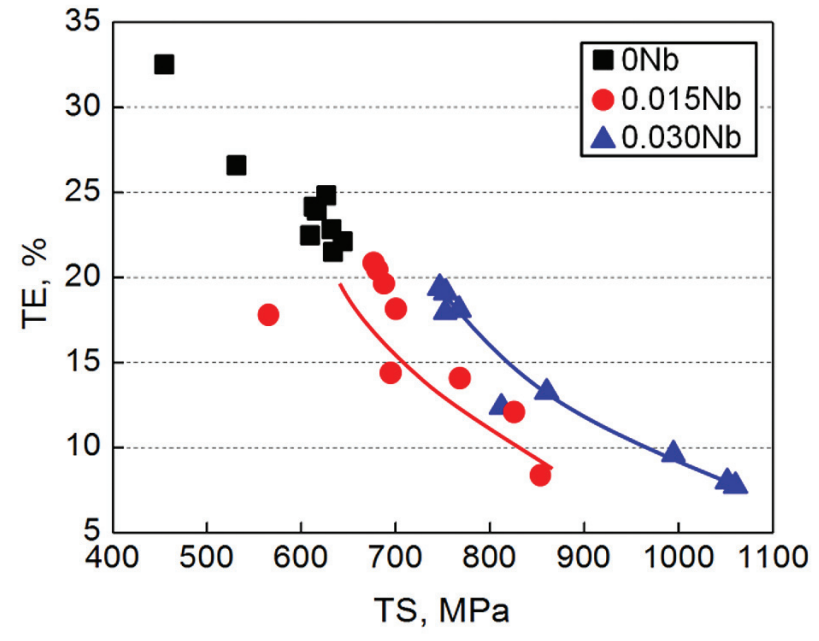

Figure I5. Effect of $\mathrm{Nb}$ on the strength - elongation balance in dualphase steels [7].

produce a variety of $3^{\text {rd }}$ Gen AHSS. This is schematically shown in Figure 17 [16].

\subsection{Carbide-Free Bainitic Steels}

The concept of bainitic steel to achieve the targets of $3^{\text {rd }}$ Gen AHSS has been studied for some time by Prof. K. Sugimoto [17-19]. The microstructure consists of carbide-free lath bainite and inter-lath retained austenite. 


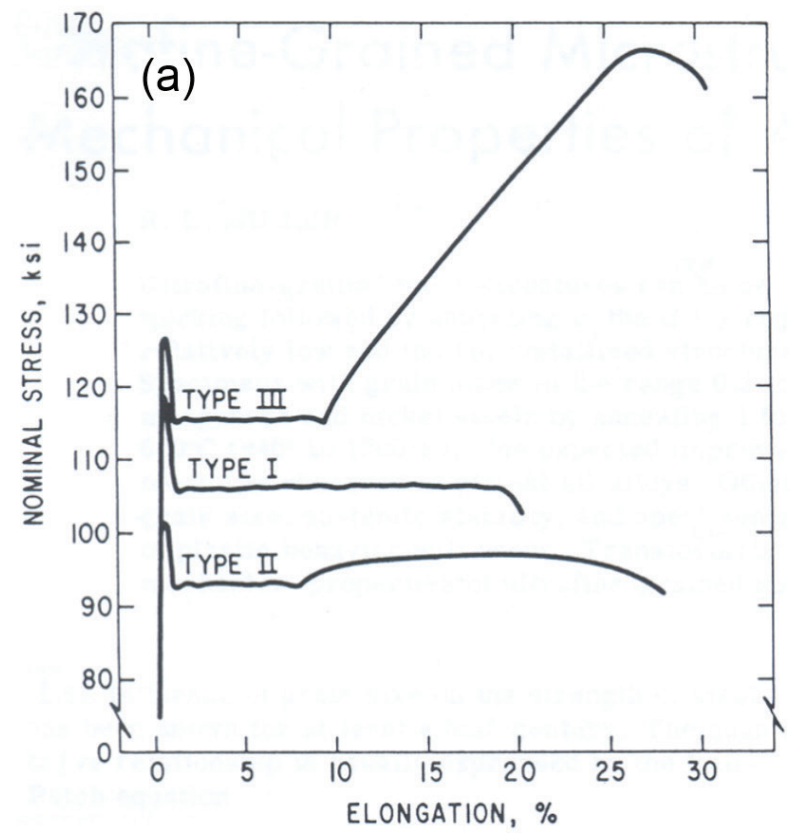

(b)

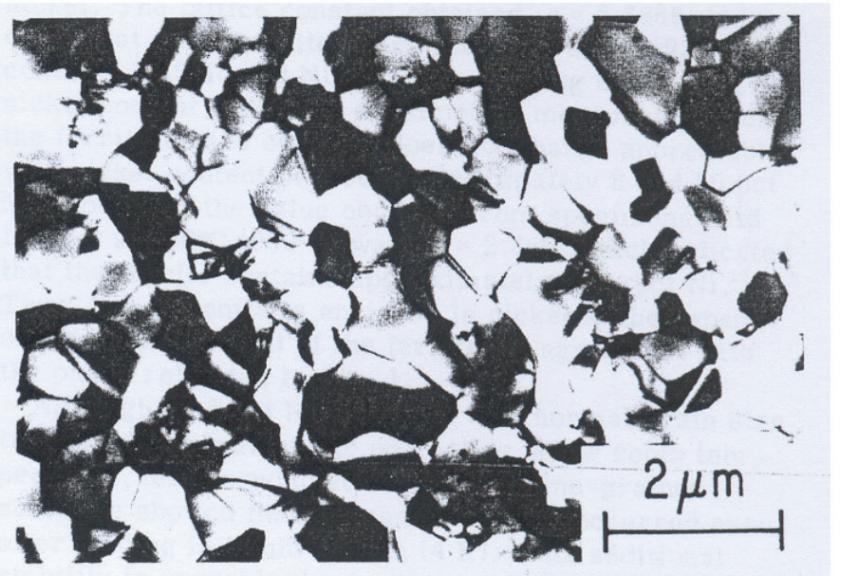

Figure 16. Stress -strain curve (a) and microstructure (b) of a $\sim 7 \% \mathrm{Mn}$ steel [15].

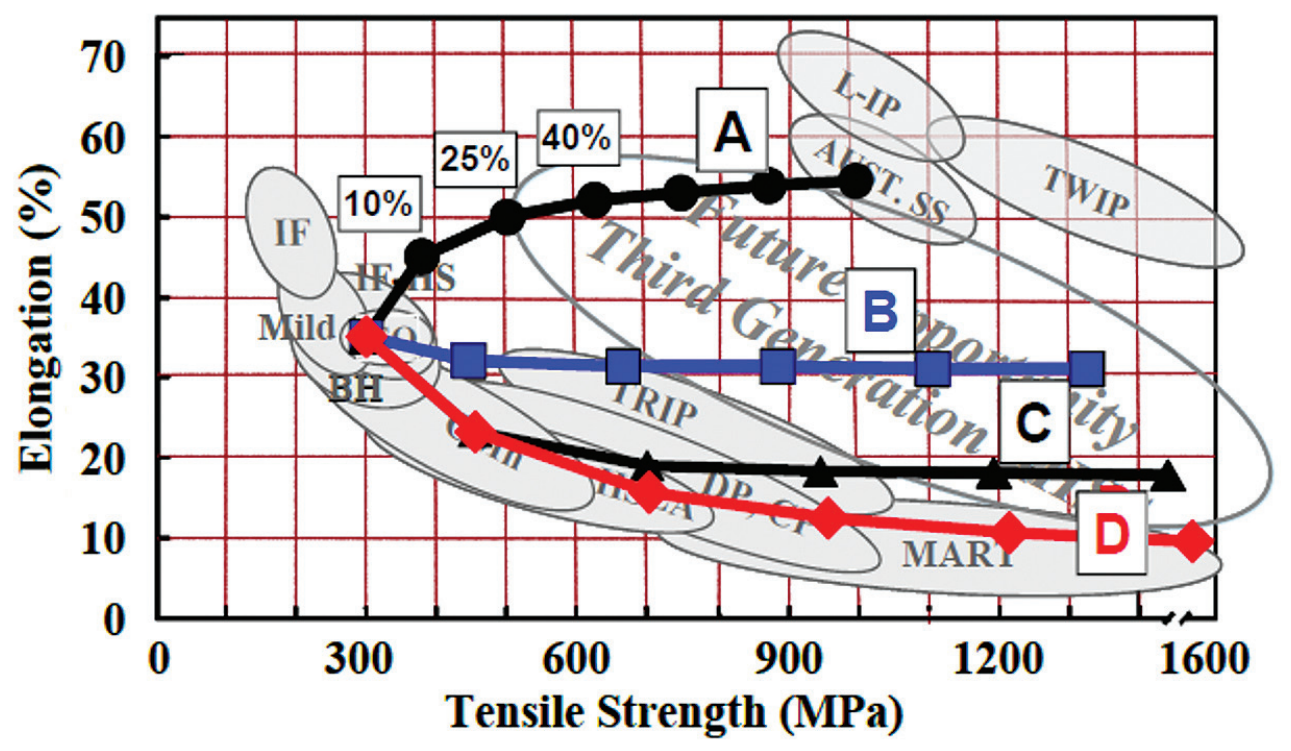

Figure 17. Mechanical properties as a function of austenite stability [16].

The absence of fine carbides and the ultrafine grain size of bainitic ferrite plates, accompanied by the contribution from the TRIP-effect in retained austenite, impart simultaneously high strength and high energy absorption. However in order to achieve high elongation at the same time as strength and HER, higher $\mathrm{C}$ than $0.20 \%$ in combination with high $\mathrm{Si}$ would be needed in these steels.

\subsection{Quenching and Partitioning Steels}

Quenching \& Partitioning (Q\&P) has been proposed recently as a new way of producing martensitic steels contai- ning enhanced levels of retained austenite [20-22]. The process, shown schematically in Figure 18 [16], consists of a two step thermal treatment where the steel is quenched to a predetermined temperature (quench temperature, QT) in the $M_{s}-M_{f}$ (i.e. martensite start temperature to martensite finish temperature) range to produce a partially martensitic, partially austenitic microstructure. The second, so-called partitioning step, aims at carbon enrichment of the austenite by (partial) carbon depletion of the martensite and carbon transport to the austenite. Thus, carbon stabilized austenite is retained in the microstructure after final quenching to room temperature. This High retained austenite 
(a)

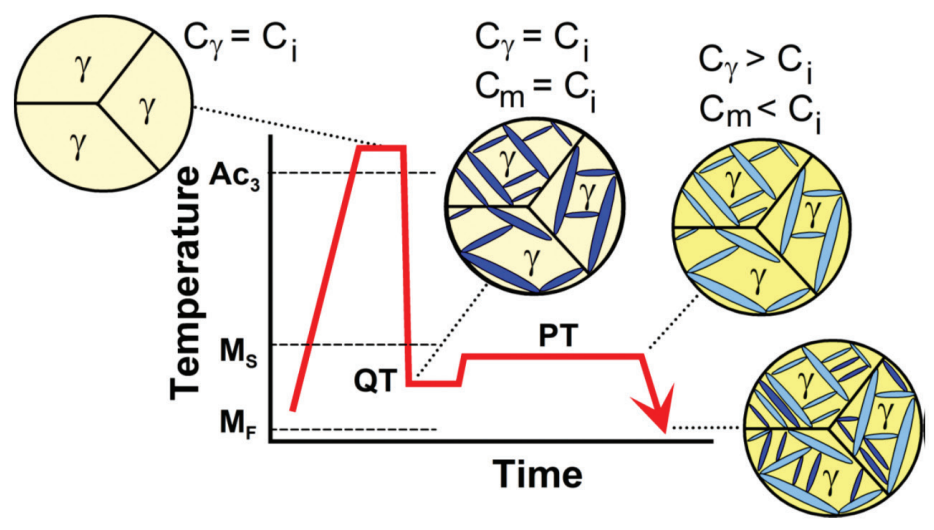

(b)

Properties of Q\&P

Summary and Comparison with AHSS

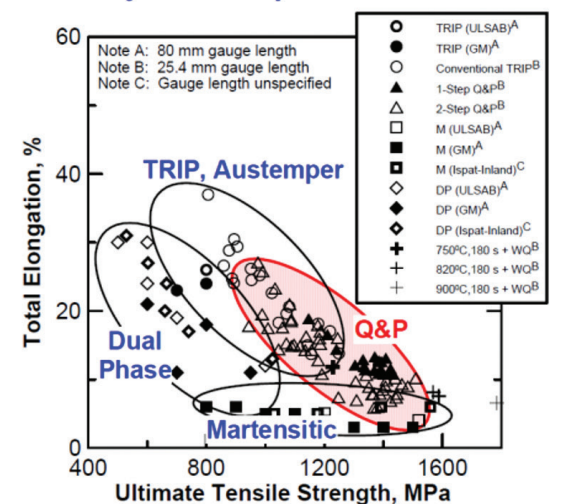

Clarke, Speer, et al. ASPPRC, Colorado School of Mines (2006)

Figure 18. (a) Schematic of the Q\&P process for production of austenite-containing microstructures starting with $100 \%$ austenite:Ci, C $\gamma$ and $\mathrm{Cm}$ respectively represent the carbon contents of the initial alloy, austenite, and martensite, (b) Mechanical properties [16].

fractionshave been shown to result in improved strength and HER. [23-25]. The results of Q\&P is shown in Figure I8.

\subsection{Press Hardened Steels (PHS)}

Although not strictly part of the $3^{\text {rd }}$ Gen AHSS, no discussion of the AHSS would be complete without including the PHS steels. This exciting development pioneered by ArcelorMittal is the production of high strenth steels during the hot stamping process. Since these are low strength steels when they are stamped, they have high formability to form complex parts but during the quenching process after the stamping, martensite is formed thus imparting very high strength in the formed part. USIBOR $1500^{\circledR}$ is an example of such a steel. Now USIBOR 2000 and DUCTIBOR steels, which are steels with enhanced ductility, are being developed. These steels would be critical for automakers to achieve the $54.5 \mathrm{mpg}$ (miles per gallon) that is required by law in the USA.

\section{SUMMARY}

AHSS, mostly with microalloying additions, are an integral part of automobile manufacturing today. While the current Ist Gen AHSS are sufficient to meet the CAFE and safety requirements of today, 3rd Gen AHSS with higher strength, improved ductility and enhanced hole expansion properties would be needed to meet the increasing demand for higher fuel efficiency, intrusion resistance and ability to form complex parts simultaneously.

\section{Acknowledgments}

The author wishes to thank all the engineers and technicians of ArcelorMittal Global R\&D who have contributed significantly to the material in this paper and CBMM for their support.

\section{REFERENCES}

I Song R, Fonstein, N., Jun, J, Pottore, N. Low carbon CR AHSS using microalloying with Nb and/or Ti. ArcelorMittalCBMM; 20I I. (Joint project Report).

2 Bhattacharya D. Role of niobium in advanced sheet steels for automotive applications. In: The Minerals, Metals \& Materials Society. Proceedings of the International Symposium on Niobium Microalloyed Sheet Steels for Automotive Applications; 2005 December 5-8; Araxá, Brazil. Araxá: TMS; 2005, p. 275-284.

3 Bhattacharya D. Niobium bearing advanced sheet steels for automotive applications at ArcelorMittal. In: Proceedings of the International Symposium on Nb-bearing Steel Technology Development. Beijing. Beijing: CITICCBMM; 2009. p. 9I-I02.

4 Girina OA, Fonstein NM, Bhattacharya D. Effect of Nb on the phase transformation and mechanical properties of advanced high strength dual-phase steels. In: New Developments on Metallurgy and Applications of High Strength Steels. Proceedings of the New Developments on Metallurgy and Applications of High Strength Steels; Argentina, Buenos Aires. Buenos Aires; 2008.

5 Bortsov AN, Fonstein NM. The Physics of Metals and Metallography. Pergamon Press for Pergamon Institute; 1984. p. $142-148$. 
6 Bhattacharya D, Girina O, Patil R. Galvatech 04. In: Association for Iron \& Steel Technology. Proceedings of the 6th International Conference on Zinc and Zinc Alloy coated Steel Sheet; 2004 April 4-7. Warrendale. Warrendale: AIST; 2004. p. 439-447.

7 Bhattacharya D. Role of niobium in advanced high strength steels for automotive applications. Beijing; $201 \mathrm{I}$.

8 Bhattacharya D, Fonstein N, Girina OA, Gupta I, Yakubovsky O, Iron \& Steel Society. A family of 590 MPa advanced high strength steels with various microstructures. In: Iron \& Steel Society. Proceedings of the 45th Mechanical Working and Steel Processing Conference. Chicago. Chicago: ISS, 2003. p. I73-I86.

9 Girina O, Fonstein N, Bhattacharya D. Effect of annealing parameters on austenite decomposition in a continuously annealed dual-phase steel. In: Iron \& Steel Society. Proceedings of the 45th Mechanical Working and Steel Processing Conference. Chicago. Chicago: ISS; 2003, p. 403-407.

10 Pottore N, Fonstein N, Gupta I, Bhattacharya D. A family of 980MPa tensile strength advanced high strength steel with various property attributes. In: Association for Iron \& Steel Technology. Proceedings of the International Conference on Advanced High Strength Sheet Steels for Automotive Applications; 2004 June 6-9; Colorado. Colorado: AIST; 2004. p. II9-129.

I I Bhattacharya D. Developments in advanced high strenght steels. Mittal Steel, East Chicago: Research and Develoment Center; 2005. p. 69-75.

I 2 Fonstein N, Jun H-J, Yakubovsky O, Song R, Pottore N. New developments in advanced high-strength sheet steels. Vail: AIST; 20I3. p. I-I3

I 3 Pickering, F. B. Physical metallurgy and the design of steels. London: Applied Science Publishers; 1978.

I4 Nakamura N. Effects of microstructures on stretch-flangeability of ultra high strengthened cold-rolled steel sheets. Camp ISIJ. 2000; I 3:39I.

I5 Miller RL. Ultrafine-grained microstructures and mechanical properties of alloy steels. Metallurgical Transactions. 1972;3(4):905-912. http://dx.doi.org/10.1007/BF02647665.

I6 Matlock DK, Speer JG, De Moor E, Gibbs PJ. Recent developments in advanced high strength sheet steels for automotive applications: an overview. Jestech. 20I2; I5(I): I-I 2.

I 7 Sugimoto K, Sakaguchi J, lida T, Kashima T. Stretch-flangeability of a high-strength TRIP type bainitic sheet steel. ISIJ International. 2000;40(9):920-926. http://dx.doi.org/10.2355/isijinternational.40.920.

I8 Sugimoto K, Kanda A, Kikuchi R, Hashimoto S, Kashima T, Ikeda S. Ductility and formability of newly developed high strength low alloy TRIP-aided sheet steels with annealed martensite matrix. ISIJ International. 2002;42(8):9I0-9I5. http://dx.doi.org/I0.2355/isijinternational.42.910.

19 Sugimoto K, Murata M, Muramatsu T, Mukai Y. Formability of C-Si-Mn-Al-Nb-Mo ultra-high-strenggth TRIP-aided sheet steels. ISIJ International. 2007;47(9): I 357-I 362. http://dx.doi.org/I 0.2355/isijinternational.47.I 357

20 Speer J, Matlock DK, De Cooman B, Schroth JG. Carbon partitioning into austenite after martensite transformation. Acta Materialia. 2003;5 I(9):26 I I-2622. http://dx.doi.org/l 0. I0 I6/SI 359-6454(03)00059-4.

2I Speer JG, De Moor E, Findley KO, Matlock DK, De Cooman BC, Edmonds DV. Analysis of microstructure evolution in quenching and partitioning automotive sheet steel. Metallurgical and Materials Transactions A, Physical Metallurgy and Materials Science. 20 I I;42(I2):359 I-360 I. http://dx.doi.org/ I0. I007/s I I 66 I-0 I I-0869-7.

22. Matlock DK, Bräutigam VE, Speer JG. Application of the Quenching and Partitioning (Q\&P) process to a mediumcarbon, high-si microalloyed bar steel. In: Proceedings of the Thermec 2003. Uetikon-Zurich, Switzerland. Uetikon-Zurich: Trans Tech Publications, Inc; 2003, p. I089-I094.

23 De Moor E, Speer JG, Matlock DK, Föjer C, Penning J. Effect of Si, Al and Mo alloying on tensile properties obtained by quenching and partitioning. In: Materials Science and Technology. Proceedings of the Materials Science and Technology (MS\&T); 2009 October 25-29; Pittsburgh, Pennsylvania. Pittsburgh: MS\&T; 2009, p. I554-I563.

24 De Moor E, Lacroix S, Clarke AJ, Penning J, Speer JG. Effect of retained austenite stabilized via quench \& partitioning on the strain hardening of martensitic steels. Metallurgical Transactions. A, Physical Metallurgy and Materials Science. 2008;39(I I):2586-2595. http://dx.doi.org/I0. I007/s I I66 I-008-9609-z.

25 De Moor E, Speer JG, Matlock DK, Kwak JH, Lee SB. Quenching and partitioning of CMnSi steels containing elevated manganese levels. In: Proceedings of the Ist International Conference on High Manganese Steels (HMnS20I I); 20 I I May I5-18; Seoul, Korea. Seoul: Yonsei University; 20 I I, p. I-9. (paper no. B-34).

Received: 25 July 2014

Accepted: 30 Oct. 2014 